\title{
Management of Pediatric Abdominal Surgical Emergencies in Northern Benin
}

\author{
M. G. Yassegoungbe ${ }^{1}$, B. Tamou Sambo ${ }^{2}$, D. M. Seto ${ }^{3}$, M. A. Hodonou ${ }^{2}$, S. B. Noukpozounkou ${ }^{1}$, \\ B. R. Assan', S. A. Allode² \\ ${ }^{1}$ Pediatric Surgery, National Teaching Hospital Hubert Koutoukou Maga, Cotonou, Benin \\ ${ }^{2}$ General Surgery, Teaching Hospital of Parakou, Parakou, Benin \\ ${ }^{3}$ University Clinic of Visceral Surgery, National Teaching Hospital Hubert Koutoukou Maga, Cotonou, Benin \\ Email: *seto.morel@gmail.com
}

How to cite this paper: Yassegoungbe, M.G., Tamou Sambo, B., Seto, D.M., Hodonou, M.A., Noukpozounkou, S.B., Assan, B.R. and Allode, S.A. (2020) Management of Pediatric Abdominal Surgical Emergencies in Northern Benin. Open Journal of Pediatrics, 10, 314-319.

https://doi.org/10.4236/ojped.2020.102032

Received: May 4, 2020

Accepted: May 31, 2020

Published: June 3, 2020

Copyright $\odot 2020$ by author(s) and Scientific Research Publishing Inc. This work is licensed under the Creative Commons Attribution International License (CC BY 4.0).

http://creativecommons.org/licenses/by/4.0/

\begin{abstract}
Background: Pediatric abdominal surgical emergencies are major causes of morbidity and mortality. The goal was to identify the main determinants of their management and access to assess their evolution. Patients and methods: This is a prospective, descriptive and analytical study performed at Parakou teaching hospital and Tanguieta district hospital. It has been conducted from January 1st to July 31st 2016. All children were included aged 0 to 15 years and admitted for an abdominal surgical emergency with a Clinical Classification of Emergency Patients listed from 3 to 5. Results: Pediatric abdominal surgical emergencies accounted for $42.8 \%$ of pediatric surgical emergencies. The average age was $9.3 \pm 3.5$ years old. The sex ratio was 1.7. The most encountered etiologies were peritonitis (36.76\%), abdominal trau$\mathrm{ma}(16.17 \%)$ and anorectal malformations (14.71\%). The comparison of the delay in operative treatment with the World Society of Emergency Surgery shows a delay in $82.35 \%$ of cases. Mortality was high preoperatively and was related to the neonatal period $(\mathrm{p}=0.027)$ and to a resuscitation length of stay higher than 36 hours $(p=0.035)$. Conclusion: Surgical care was delayed, mainly due to the lack of technical capacities. Morbidity and mortality were relatively low.
\end{abstract}

\section{Keywords}

Abdominal Surgical Emergency, Pediatrics, Peritonitis, Delay in Surgery

\section{Introduction}

In the pediatric environment, the diagnosis of abdominal surgical emergencies (ASE) is a real challenge for the surgeon, due to the usual severe prognosis [1] 
[2]. The success of their care depends on the organization put in place. Unfortunately in Africa, pediatric surgery is not yet developed. Therefore, almost all cases are treated in adult surgical department. The main determinants identification and the management, morbidity and mortality assessment of pediatric abdominal surgical emergencies could lead to a real clinical and health interest.

\section{Patients and Methods}

This is a prospective, descriptive and analytical study realized in Parakou teaching hospital and Tanguieta district hospital. The study covered a period of 7 months from January 1st 2016 to July 31st 2016. Were included children aged from 0 to 15 years and admitted for an abdominal surgical emergency with a clinical classification of patients with emergencies (known as CCMU: Classification Clinique des Malades aux Urgences) quoted at 3, 4 or 5. CCMU is a score that allows the evaluation of patients in care in emergency department [3]. It comprises 7 degrees of severity: CCMU P (patient with a psychiatric pathology); CCMU 1 (patient considered stable); CCMU 2 (patient considered stable with a decision of complementary diagnostic or therapeutic act); CCMU 3 (patient whose condition is likely to worsen without being life-threatening); CCMU 4 (patient whose vital prognosis is engaged without need of imperative resuscitation maneuver); CCMU 5 (patient whose vital prognosis is engaged with imperative necessity of a resuscitation maneuver); CCMU D (deceased patient without any resuscitation maneuver). The distribution of children in age groups was the following: new-borns (0 to 28 days); infants: (29 days to 30 months); children (after 30 to 120 months) and adolescents (beyond 120 months).

The variables studied were the diagnosis delay, the preoperative resuscitation duration, the time for surgical management, the indication for surgery; complications and mortality. The time elapsed between the admission and the diagnosis was the diagnosis delay and the one between the diagnosis and the surgical procedure beginning, the time for surgical management. The delay in surgical management is defined by an operative time beyond the "Time of Acute Care Surgery (TACS)" defined by the "World Society of Emergency Surgery (WSES)" [4].

Collected data was analyzed using the Epi Info 7.2 software. Statistical tests used were arithmetic variance, $\mathrm{Chi}^{2}$ and FISHER test. For comparisons, a probability $\mathrm{p}<0.05$ was considered as statistically significant.

\section{Results}

\subsection{Sociodemographic and Diagnostic Data}

68 cases of pediatric abdominal surgery emergency (PASE) were recruited, representing $42.8 \%$ of surgical emergencies in children and $27.6 \%$ of pediatric surgical activities. There were 43 boys (63.2\%) and 25 girls (36.8\%) with a sex ratio at 1.7. The average age was $9.3 \pm 3.5$ years with the extremes 1 day and 15 years. The average time for consultation was 5 days. The emergencies included 
non-traumatic abdominal surgical emergencies (NTASE), 83.8\%, and traumatic abdominal surgical emergencies (TASE), 16.2\%. Table 1 shows the distribution of these different emergencies.

\subsection{Therapeutic Data}

The average resuscitation duration was $22.8 \pm 1$ hours with extremes 25 minutes and 11 days. Out of the 68 children who had abdominal surgical emergencies, 62 were operated representing a percentage of $91.2 \%$.

The average time for surgical management was 22 hours with the extremes 20 minutes and 10.8 days. Table 2 shows that there was a delay in surgical management for all categories of interventions. Many factors were associated with that delay such as the patient age $(\mathrm{p}=0.07)$; the pathology severity $(\mathrm{p}=0.7)$; the lack of technical means $(\mathrm{p}=0.01)$ and the lack of proficient personnel $(\mathrm{p}=0.6)$. The different surgical procedures performed are shown in Table 3.

Table 1. Distribution of different pediatric abdominal surgical emergencies.

\begin{tabular}{ccc}
\hline & Population size & $(\%)$ \\
NTASE & 25 & 36.8 \\
Acute generalized peritonitis & 10 & 14.7 \\
Anorectal malformations & 8 & 11.8 \\
Acute intestinal obstruction & 6.8 \\
Acute intussusception & 6 & 5.9 \\
Incarcerated hernia & 3 & 4.4 \\
Acute appendicitis & 1 & 1.4 \\
Intra-abdominal foreign body & & 10.3 \\
TASE & 68 & 100 \\
Abdominal blunt & 7 & 5.9 \\
Abdominal wound & 4 & \\
TOTAL & 68 & \\
\hline
\end{tabular}

Table 2. Time taken for WSES and our series.

\begin{tabular}{llll}
\hline & $\begin{array}{l}\text { Ideal time between diagnosis and } \\
\text { intervention according to WSES }\end{array}$ & $\begin{array}{l}\text { Code } \\
\text { colour }\end{array}$ & $\begin{array}{l}\text { Our } \\
\text { series }\end{array}$ \\
\hline $\begin{array}{lll}\text { Haemorrhagic emergency } \\
\begin{array}{l}\text { Strangulated hernia, viscera } \\
\text { perforation, diffuse peritonitis, } \\
\text { soft tissue infection associated } \\
\text { with sepsis }\end{array}\end{array}$ & $\begin{array}{l}\text { Surgical intervention within } 1 \\
\text { hour }\end{array}$ & $3.3 \mathrm{~h}$ \\
$\begin{array}{l}\text { Soft tissue infection not associated } \\
\text { with sepsis }\end{array}$ & $\begin{array}{l}\text { Surgical intervention within } 6 \\
\text { hours }\end{array}$ & $18.7 \mathrm{~h}$ \\
Appendicitis, cholecystitis & $\begin{array}{l}\text { Surgical intervention within } 12 \\
\text { hours }\end{array}$ & \\
\end{tabular}


Table 3. Distribution of children operated for an abdominal surgical emergency according to the surgical procedure.

\begin{tabular}{|c|c|c|c|}
\hline & Surgical gesture & Population size & $\%$ \\
\hline \multirow{3}{*}{ Peritonitis } & Excision-suture washing and drainage & 18 & 29 \\
\hline & Appendectomy washing and drainage & 4 & 6.4 \\
\hline & Resection-ileal anastomosis & 3 & 4.8 \\
\hline MAR & Colostomy according to Pena & 9 & 14.5 \\
\hline \multirow{3}{*}{$\begin{array}{l}\text { Acute bowel } \\
\text { obstruction }\end{array}$} & Bridle section & 2 & 3.2 \\
\hline & Adhesiolysis flange section & 2 & 3.2 \\
\hline & Devolvulation & 1 & 1.6 \\
\hline \multirow{2}{*}{$\begin{array}{l}\text { Acute intestinal } \\
\text { intussusception }\end{array}$} & Disinvagination & 3 & 4.8 \\
\hline & Disinvagina resection anastomosis & 2 & 3.2 \\
\hline \multirow{2}{*}{ Incarcerated hernia } & Cure hernia & 3 & 4.8 \\
\hline & Hernial curing umbilicus fixation & 1 & 1.6 \\
\hline \multirow{2}{*}{ Appendicitis } & Appendectomy & 2 & 3.2 \\
\hline & Appendectomy drainage & 1 & 1.6 \\
\hline $\begin{array}{l}\text { Intra-abdominal } \\
\text { foreign body }\end{array}$ & Gastrotomy and extraction & 1 & 1.6 \\
\hline \multirow{3}{*}{$\begin{array}{l}\text { Abdominal } \\
\text { Contusion }\end{array}$} & Washing Drainage & 4 & 6.4 \\
\hline & Splenectomy wash drainage & 1 & 1.6 \\
\hline & Vesico-urethral drainage suture & 1 & 1.6 \\
\hline \multirow{2}{*}{$\begin{array}{l}\text { Penetrating wound } \\
\text { of the abdomen }\end{array}$} & Excision suture & 2 & 3.2 \\
\hline & Resection anastomosis & 2 & 3.2 \\
\hline Total & & 62 & 100 \\
\hline
\end{tabular}

\subsection{Evolutive Data}

During preoperative resuscitation, 6 deaths occurred, representing $8.8 \%$ of preoperative deaths. Neonatal period and resuscitation time higher than 36 hours significantly influenced preoperative death $(\mathrm{p}=0.027$ and $\mathrm{p}=0.035$, respectively). For operated children $(n=62)$, post-operative history was complicated in 9.7\% $(n=6)$. There were 3 cases of deep suppuration, 2 two of parietal suppuration and one of postoperative peritonitis. The postoperative mortality rate was $4.8 \%(\mathrm{n}=3)$.

\section{Discussion}

\subsection{Sociodemographic and Diagnostic Data}

The average age of the patients in this study was 9.3 years. That age is similar to the one reported from a study conducted by Pujari et al. in India [5] and Abantanga et al. in Ghana [1] respectively at 7 and 8.8. The sex ratio at 1.7 is close to 1.5 found by Abantanga et al. [1] and Abubakar et al. in Nigeria [6].

The average time for consultation was 5 days. This is superior to 2 days reported by the Harouna et al. in Niger [7] and 4 days in the Nigerian series by Abubakar et al. [6]. Delay in consultation is frequent in our context as reported in many other previous studies in sub-Saharan Africa [8] [9] [10]. It would be related to many factors including ignorance of parents, prior use of traditional 
medicine and sometimes to misdiagnosis.

\subsection{Therapeutic Data}

22.8 hours as resuscitation duration was very long in the context of the severe emergencies. It had led to the death of six children. In fact, the resuscitation time greater than 36 hours significantly influenced preoperative death $(\mathrm{p}=0.035)$. The neonatal period also influenced the occurrence of death during preoperative resuscitation $(\mathrm{p}=0.027)$.

The time for surgical management was 22 hours. Basing on WSES classification [4], we were able to conclude that the average time for surgical management was not adequate. This delay in management was mainly due to the inadequacy of the technical capacities $(\mathrm{p}=0.01)$.

As peritonitis is the main diagnosis, it directed the majority of surgical procedures toward excision, intestinal suture with washing and drainage. Perforation is very common in Africa and associated with typhoid fever. Typhoid fever is a disease encountered in regions with low socioeconomic level and leads to ileal perforation as complication [11]. Colostomy according to Pena was the colostomy technique performed in case of anorectal malformation and it was effective given the absence of postoperative complication in our study.

\subsection{Evolutive Data}

Postoperative morbidity in our study was $9.7 \%$ with a deep suppuration predominance. In Niamey, Harouna $\mathrm{Y}$ et al. [7] reported a rate of 55\% among infants treated for intussusception in a general surgery department in 2000. They attributed this very high rate to the delay in diagnosis, the problems of resuscitation and the lack of pediatric surgeon. Postoperative mortality is low compared to $23 \%$ reported by Matoko et al., [12] and 22.8\% by Mhando S et al. [13].

\section{Conclusion}

Pediatric abdominal surgical emergencies mostly affected boys and the time for consultation was long. Peritonitis and anorectal malformations were the main diagnoses in our context. Operative management was delayed, mainly due to the lack of adequate technical capacities. Morbidity and mortality were relatively low in comparison with other series.

\section{Conflicts of Interest}

The authors declare no conflicts of interest regarding the publication of this paper.

\section{References}

[1] Abantanga, S., Nimako, B. and Amoah, M. (2009) The Range of Abdominal Surgical Emergencies in Children Older than 1 Year at the Komfo Anokye Teaching Hospital, Kumasi, Ghana. Annals of African Medicine, 8, 236-242. https://doi.org/10.4103/1596-3519.59578 
[2] Williams, N.M.A., Johnstone, J.M. and Everson, N.W. (1998) The Diagnostic Value of Symptoms and Signs in Childhood Abdominal Pain. Journal of the Royal College of Surgeons of Edinburgh, 43, 390-392.

[3] Fourestie, V., Roussignol, E., Elkharrat, D., Rauss, A. and Simon, N. (1994) Classification clinique des malades des urgences: Définition et reproductibilité. Réanimation Urgences, 3, 5738. https://doi.org/10.1016/S1164-6756(05)80760-1

[4] Kluger, Y., Offir, B.I., Massimo, S., Luca, A., Ashraf, E.A., Ferdinando, A., et al. (2013) World Society of Emergency Surgery Study Group Initiative on Timing of Acute Care Surgery Classification (TACS). World Society of Emergency Surgery, 8, 17. https://doi.org/10.1186/1749-7922-8-17

[5] Pujari, A.A., Methi, R.N. and Khare, N. (2008) Acute Gastrointestinal Emergencies Requiring Surgery in Children. African Journal of Paediatric Surgery, 5, 61-64. https://doi.org/10.4103/0189-6725.44177

[6] Abubakar, A.M. and Ofoegbu, C.P. (2003) Factors Affecting Outcome of Emergency Paediatric Abdominal Surgery. The Nigerian Journal of Surgical Research, 5, 85-91. https://doi.org/10.4314/njsr.v5i3.12247

[7] Harouna, Y., Tardivel, G., Abdou, I., Gamatie, Y., Mariama, S. and Bia, M. (1997) Pronostic de l'invagination intestinale aiguë du nourrisson à l'hôpital national de Niamey (Niger). A propos de 11 cas traités chirurgicalement. Bulletin de la société de pathologie exotique, 90, 59-63.

[8] Ademuyiwa, A.O., Bode, C.O., Adesanya, O.A. and Elebute, O.A. (2012) Non-Trauma Related Paediatric Abdominal Surgical Emergencies in Lagos, Nigeria: Epidemiology and Indicators of Survival. Nigerian Medical Journal, 53, 76-79. https://doi.org/10.4103/0300-1652.103546

[9] Mabiala-Babela, J.R., Pandzou, N., Koutaba, E., Ganga, Z.S. and Senga, P. (2006) Etude rétrospective des urgences chirurgicales viscérales de l'enfant au CHU de Brazzaville (Congo). Med Trop, 66, 172-176.

[10] Mbah, N., Opara, W.E. and Agwu, N.P. (2006) Waiting Time among Acute Abdominal Emergencies in a Nigerian Teaching Hospital: Causes of Delay and Consequences. Nigerian Journal of Surgical Research, 8, 69-73. https://doi.org/10.4314/njsr.v8i1.54835

[11] Ibrahim, M., Getso, K.I., Yashuwa, A.H., Mohammad, A.M. and Ayanwu, L.J.C. (2013) Single-Layer Closure of Typhoid Enteric Perforation: Our Experience. African Journal of Paediatric Surgery, 10, 167-171. https://doi.org/10.4103/0189-6725.115046

[12] Motoko, G.M., Tshipanda, V.K., Mwebe, I.M., Kakala, J.P.B. and Mputu, J.B.Y. (2014) Prise en charge des abdomens aigus chirurgicaux chez l'enfant aux Cliniques Universitaires de Kinshasa. Annals of African Medicine, 8, 1-9.

[13] Mhando, S., Young, B. and Lakhoo, K. (2008) The Scope of Emergency Paediatric Surgery in Tanzania. Pediatric Surgery International, 24, 219-222. https://doi.org/10.1007/s00383-007-2072-x 